\title{
MENCIPTAKAN ENTREPRENEUR MUDA UNTUK MEMBUKA KESADARAN ATAS PENTINGNYA KEWIRAUSAHAAN BAGI PESERTA DIDIK
}

\author{
SITI FATIMATUS JAHROH \\ Program Studi Pendidikan Guru Sekolah Dasar \\ Fakultas Keguruan dan Imu Pendidikan \\ Universitas Nahdlatul Ulama Sidoarjo \\ Email: stfatimatusjahroh99@gmail.com
}

\section{Pengantar}

Sekolah merupakan sebuah lembaga pendidikan yang mempunyai tujuan untuk mencerdaskan kehidupan bangsa. Dimana di dalam sekolah itu terjadi proses belajar mengajar antara peserta didik dengan para pengajar atau yang biasa disebut dengan guru. Sekolah, memberikan pendidikan atau ilmu yang akan menjadi bekal dalam kehidupan bermasyarakat kelak setelah lulus. Dimana pendidikan ilmu itu tidak diberikan oleh orang tua di rumah. (Saroni, 2012) menjelaskan bahwa sekolah merupakan proses belajar, yang artinya adalah sebuah proses untuk menyesuaikan diri terhadap lingkungan luar. Dan sekolah juga mencoba untuk mengatur para peserta didik supaya mampu dalam menghadapi kehidupan selanjutnya dengan baik. Hal tersebut mengartikan bahwa para peserta didik harus mampu membekali dirinya tidak hanya dengan ilmu pengetahuan maupun sikap positif, tetapi juga harus disertai dengan sebuah keterampilan aplikatif untuk kehidupannya kelak.

Pendidikan di Indonesia bertujuan untuk mencerdaskan kehidupan bangsa dimana ditekankan pada pendidikan moral agar meningkatkan iman, taqwa, serta akhlak atu perilaku yang mulia dengan berlandaskan nilai-nilai yang ada pada Pancasila. (Wirawan, 2014) menerangkan bahwa tujuan pendidikan di Indonesia adalah untuk meningkatkan keimanana, ketakwaan, dan akhlak mulia. Dengan adanya kualitas pribadi yang lebih baik, diharapkan para lulusan pendidikan mampu menjadi lebih baik lagi serta mampu untuk membangun bangsa.

Pemanfaatan waktu luang di dalam kegiatan proses belajar hendaknya diisi dengan melakukan kegiatan yang positif. Dimana kegiatan positif tersebut diharpakan sebagai bekal dalam kehidupan dimasa yang akan datang setelah lulus dari sekolah. Dengan demikian, hal tersebut berarti dapat mengurangi bertambahnya jumlah pengangguran yang terdidik di negara ini. (Saroni, 2012) 
memaparkan bahwa setiap tahunnya, di negeri ini jumlah penganggurannya terus mengalami perkembangan yang berupa peningkatan. Hal itu dikarenakan setiap tahunnya sekolah meluluskan sekian banyak peserta didik yang belum mampu maupun belum siap untuk memasuki lapangan pekerjaan. Hal tersebut tentu merugikan, karena waktu belajar serta biaya yang dikeluarkan untuk belajar ternyata tidak berkontribusi dalam kehidupan yang lebih baik.

Untuk mengatasi masalah tersebut, baik dari pihak pemerintah maupun pihak dari swasta mendirikan sekolah kejuruan yang nantinya menghasilkan lulusan yang siap dan mampu untuk memasuki dunia pekerjaan yang sesuai dengan keterampilan yang telah dimiliki oleh para peserta didik. (Saroni, 2012) menjelaskan bahwa tujuan pendidikan dan pembelajaran di sekolah kejuruan adalah untuk membimbing para peserta didik supaya mampu menjadi tenaga kerja kelas menengah yang siap untuk bekerja. Sekolah kejuruan lebih mengutamakan proses pembelajaran yang aplikatif (praktik) dengan kompetensi keahlian untuk para peserta didiknya. Hal itu menjadi lebih nyata karena didukung dengan adanya program-program kewirausahaan yang dilaksanakan secara integral serta dengan program pembelajaran.

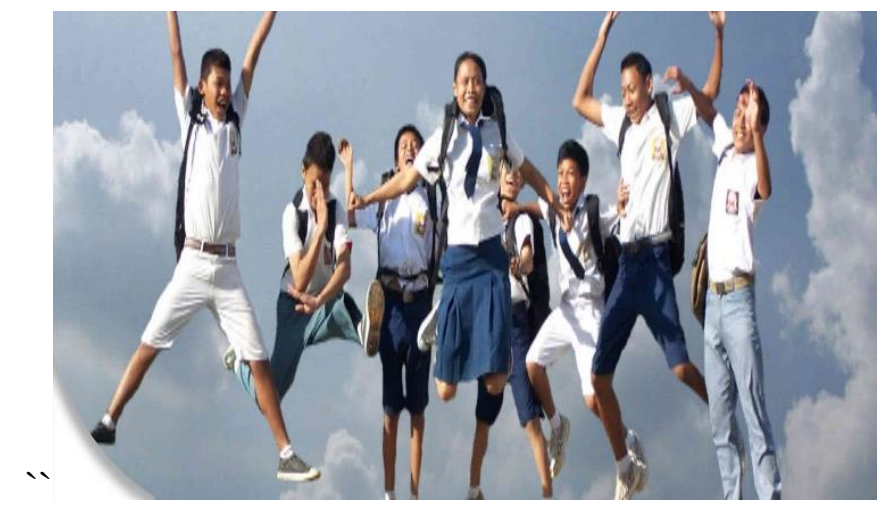

Setiap masalah pasti akan ada jalan keluarnya. Jalan keluar dari masalah itu diharapkan mampu untuk menjadi pemecah atau langkah dalam menyelesaikan sebuah masalah. Berikut ini penulis mencoba untuk memaparkan tiga cara melahirkan entrepreneur muda dari sekolah. 


\section{Spesifikasi Program di Sekolah Kejuruan}

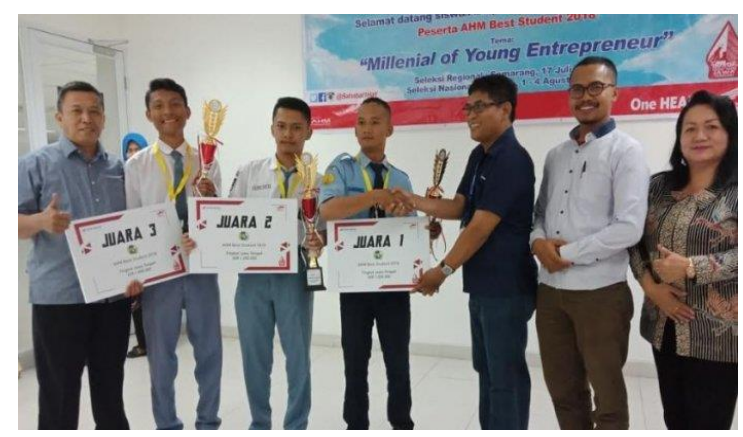

Pendidikan di sekolah kejuruan yaitu peserta didik mendapatkan materi setelah mendapatkan materi kemudian diterapkan atau lebih sering disebut dengan kegiatan praktik. Kegiatan praktik membuat keterampilan peserta didik menjadi lebih terasah dan menjadikan keterampilan itu sebagai bekal ketika nanti setelah lulus menjadi tenaga kerja. Kegiatan praktik juga membuat peserta didik lebih produktif menghasilkan barang dan jasa. (Saroni, 2012) menjelaskan pendidikan kejuruan mempersiapkan peserta didiknya sebagai tenaga kerja kelas menengah yang siap untuk bekerja di masyarakat. Model pembelajaran yang digunakan adalah pembelajaran dengan konsep learning by doing dimana merupakan program pendidikan yang menempatkan konsep sebenarnya yaitu efektivitas pembelajaran yang bisa dicapai peserta didik jika mengalami secara langsung apa yang telah mereka pelajari. Spesifikasi program di sekolah kejuruan bisa dilihat dari materi pembelajaran yaitu pembelajaran produktif yang mengarahkan peserta didik supaya dapat menghasilkan barang atau jasa. Hal itu sesuai dengan tujuan dari sekolah kejuruan yaitu menghasilkan lulusan yang siap untuk bekerja.

\section{A. Sekolah Keterampilan}

Sekolah keterampilan merupakan sebuah institusi pendidikan yang mengutamakan keterampilan dalam proses pembelajaran anak didiknya. Dengan diberikannya keterampilan diharapkan supaya ada nilai tambahan pada diri peserta didik. Dalam upaya membuka kesadaran berwirausaha, perlu mengaplikasikan sekolah menjadi sentral pengembangan serta peningkatan kualitas keterampilan peserta didik. Pendidikan dan pembelajaran keterampilan dijadikan program unggulan, maka akan memberikan nilai plus bagi peserta didik. Tentunya sekolah harus mampu membimbing dan memfasilitasi kemampuan peserta didiknya supaya memiliki kemampuan yang sesuai dengan kebutuhan masyarakat. Dengan kondisi tersebut sekolah telah melakukan antisipasi atas meningkatnya jumlah pengangguran. Justru peserta didik bisa menciptakan lapangan pekerjaan bagi orang lain. Contoh sekolah keterampilan antara lain yaitu, tata busana, tata kecantikan, dsb 


\section{B. Sekolah Pelatihan}

Sekolah pelatihan menerapkan proses pembelajaran yang proporsional, yang artinya memberikan persiapan kepada peserta didik untuk menghadapi kehidupan di masyarakat. Dengan hal itu, ketika peserta didik telah menyelesaikan masa belajarnya mereka akan mampu menerapkan hasil pelatihannya serta mampu melakukan kegiatan kerja karena kemampuan dirinya sesuai dengan kebutuhan di masyarakat. Sebagai contoh perkembangan teknologi pada zaman sekarang sangat berkembang pesat dan setiap lapisan masyarakat pasti mempunyai barang teknologi tersebut. Sementara mereka belum menguasai segi perawatan dan perbaikan barang-barang tersebut jika mengalami kerusakan. Pada kondisi inilah peserta didik diberikan pelatihan supaya mampu menerapkan hasil pelatihannya. Contoh sekolah pelatihan adalah sekolah jurusan perhotelan, tata niaga, multimedia, teknik mesin, dll.

\section{Sekolah Industri}

Sekolah industri adalah sekolah yang mengorientasikan semua kegiatan pembelajaran dan pendidikannya seperti sebuah industri dimana setiap orang yang terlibat dalam proses pembelajaran harus punya visi dan misi yang dalam untuk meningkatkan kualitas proses serta hasilnya. Maka sekolah harus memberikan peluang kepada peserta didik untuk berada dalam lingkungan yang menuntutnya "bekerja" seperti seharusnya. Atas adanya industri di lingkungan sekolah, peserta didik bisa mengikuti pendidikan teori di sekolah dan menerapkan teori tersebut pada praktik di industry yang ada. Di dalam konsep kewirausahaan, sekolah bisa mengembangkan bidang produksi dan jasa serta melayani kebutuhan masyarakat. Contoh sekolah industri adalah sekolah jurusan pemesinan pesawat udara, kontruksi badan pesawat udara, kontruksi rangka pesawat udara, dsb.

\section{Bekal Keterampilan yang Harus Dimiliki Entrepreneur Muda}

Keterampilan merupakan modal utama bagi seorang entrepreneur. Karena dengan keterampilan mampu menciptakan lapangan pekerjaan. Keterampilan setiap peserta didik itu berbeda-beda, maka peserta didik harus diberi pengajaran sesuai dengan keterampilan yang dimilikinya. Peserta didik harus dibekali dengan keterampilan usaha maupun keterampilan teknis supaya siap ketika nanti siap terjun ke dunia pekerjaan. Sebab tanpa bekal keterampilan kewirausahaan tidak akan berhasil. (Saroni, 2012) menjelaskan bahwa untuk menciptakan entrepreneur muda dari sekolah harus memiliki bekal keterampilan. Entrepreneur muda harus dibekali dengan keterampilan teknik dan keterampilan usaha. Keterampilan teknis adalah bekal untuk melaksanakan kegiatan produksi atau menciptakan barang ataupun jasa 
yang dibutuhkan oleh masyarakat. Keterampilan usaha merupakan follow up kegiatan produksi yang telah dilakukan oleh peserta didik dalam proses pembelajaran. Pembelajaran keterampilan usaha mengkondisikan peserta didik supaya mampu menerapkan konsep-konsep usaha yang mengutamakan kemampuan diri serta membimbing untuk mengembangkan diri dengan interaksi pada masyarakat secara aktif. Peserta didik dapat menjadi sosok yang terampil dalam melaksanakan kegiatan wirausaha, selanjutnya hal itu adalah suatu bekal aplikatif untuk bersaing dalam kehidupan.

\section{Pentingnya Keterampilan Usaha}

Keterampilan usaha sangatlah penting bagi entrepreneur agar tidak tergerus karena semakin sempitnya dunia kerja. Untuk peserta didik, keterampilan usaha mendukung kesiapan peserta didik supaya mampu menghadapi kehidupannya di masyarakat kelak setelah lulus. (Saroni, 2012) menerangkan bahwa dengan keterampilan berwirausaha, peserta didik dapat mandiri selanjutnya peserta didik tidak lagi menggantungkan hidupnya dengan mencari pekerjaan, tetapi mampu menciptakan lapangan pekerjaan.

\section{A. Keterampilan sebagai Brandingself Anak Didik}

Keterampilan khusus yang dimiliki peserta didik adalah hasil proses pendidikan dan pembelajaran merupakan brandingself atau citra dirinya. Keterampilan khusus tersebut merupakan bekal untuk menghadapi kehidupan yang semakin ketat persaingannya. Dengan adanya brandingself, terdapat nilai plus yang mempunyai nilai jual dalam kehidupan masyarakat. Jika peserta didik sudah memiliki brandingself, maka peserta didik tidak perlu lagi mencari pekerjaan karena mereka merupakan tenaga-tenaga kerja yang aplikatif dan sudah mampu untuk bekerja serta memiliki target pasar sejak menempuh pendidikan dan pembelajaran, sebab mereka telah bekerja sejak menempuh pendidikan dan pembelajaran.

\section{B. Keterampilan sebagai Pertanggung Jawaban Moral Pendidikan}

Setiap program yang disusun selalu merujuk pada upaya untuk membuat peserta didik sebagai sosok efektif dalam kehidupannya serta didasarkan pada pemahaman bahwa proses pendidikan dan pembelajaran memiliki tanggung jawab moral untuk kehidupan peserta didik ataupun masyarakat di kemudian hari. Tanggung jawab moral dunia pendidikan (guru dan sekolah) terkait dengan masa depan peserta didik. Sebab jika benar dalam memberi bekal proses pendidikan, di masa depan peserta didik akan menjadi orang-orang yang bertanggung jawab terhadap kehidupannya. 


\section{Rangkuman}

Untuk menciptakan entrepreneur muda dari sekolah dengan melihat spesifikasi program di sekolah kejuruan, memberikan bekal keterampilan yang harus dimiliki entrepreneur muda, serta pentingnya keterampilan usaha bagi entrepreneur muda. Spesifikasi program di sekolah kejuruan terdiri dari tiga hal, yaitu sekolah keterampilan, sekolah pelatihan, dan sekolah industri. Bekal keterampilan yang harus dimiliki entrepreneur muda adalah keterampilan berupa keterampilan usaha dan keterampilan teknis. Pentingnya keterampilan usaha bagi entrepreneur muda yaitu sebagai brandingself bagi peserta didik serta sebagai pertanggung jawaban moral pendidikan.

\section{References}

Saroni, M. (2012). Mendidik \& Melatih Entrepreneur Muda Membuka Kesadaran Atas Pentingnya Kewirausahaan bagi Anak Didik. Jogjakarta: Ar-Ruzz Media.

Wirawan, M. J. (2014). Internalisasi Jiwa Kewirausahaan pada Anak. Jakarta: Kencana Prenadamedia Group.

Purnomo, A. (2017, December 5). Pengertian Edupreneur. 